\title{
Resolusi Spasial Optimum pada Citra Drone untuk Klasifikasi Spesies Mangrove dengan Metode Maximum Likelihood
}

\section{Optimum spatial resolution of drone imageries for mangrove species classification with} Maximum Likelihood method

\author{
Monika Ruwaimana $^{1^{*}}$, Novian Atmaja ${ }^{2}$, Ign. Pramana Yuda ${ }^{1}$ \\ ${ }^{1}$ Fakultas Teknobiologi, Univertas Atma Jaya Yogyakarta, Daerah Istimewa Yogyakarta \\ ${ }^{2}$ Kantor Sistem Informasi, Universitas Atma Jaya Yogyakarta, Daerah Istimewa Yogyakarta \\ E-mail: monruw@gmail.com; monika_ruwaimana@mail.uajy.ac.id *penulis untuk korespondensi
}

\begin{abstract}
Drone is one of the current ecological remote sensing research tool. It could fly much lower compared to an airplane and a satellite. Moreover, itprovides detailed images or higher spatial resolutions, which could reach sub-centimetre. Research on mangrove species classification with drone image is still limited in number, and there is no reference on optimum spatial resolution for classification. Here we hypothesized that there is a linear relationship between spatial resolution and mapping accuracy, where the reductionof spatial resolution will also reduce the species classification accuracy. Based on that, we conduct an experiment with 8 different spatial resolution, i.e. $2.5 \mathrm{~cm}, 5 \mathrm{~cm}, 10 \mathrm{~cm}, 20 \mathrm{~cm}, 40 \mathrm{~cm}, 60 \mathrm{~cm}, 80 \mathrm{~cm}$ and $100 \mathrm{~cm}$, with 9 iterations for each image. The result is against our former hypothesis, as it shows that there is no significant map accuracy reduction, where the Overall Accuracy $(O A)$ in $2.5 \mathrm{~cm}$ resolution is $84.97 \pm 2.37 \%$, and in $60 \mathrm{~cm}$ is $88.61 \pm 3.6 \%$. Instead of showing reduction, thisresult shows a slightly increase of accuracy when the resolution is decreasing, even though it is not significant. However, in $100 \mathrm{~cm}$ spatial resolution, the accuracy is significantly lower $(\mathrm{OA}=\mathbf{2 0 . 7 2} \pm 1.24 \%)$. Based on those results, we recommend the resolution of $60 \mathrm{~cm}$ for mangrove species identification, firstly, because this reduction in resolution (from $2.5 \mathrm{~cm}$ to $60 \mathrm{~cm}$ ) could save a lot of time analysis (from 15 min to 2.5 sec). Secondly, but at utmost importance, this resolution shows highest mapping accuracy for species with high heterogeneity like palm $N$. fruticans, without significantly reduce the accuracy of mangrove trees like $R$. apiculata and A. alba.
\end{abstract}

Keywords: Drone, UAV, mangrove, spatial resolution, Maximum Likelihood

\begin{abstract}
Abstrak
Drone adalah salah satu alat baru dalam penelitian berbasis remote sensing pada studi ekologi hutan mangrove, drone dapat terbang jauh lebih rendah dibandingkan pesawat pemetaan, sehingga citra yang ditangkap akan lebih detail atau memiliki resolusi spasial yang tinggi; citra drone dapat mencapai resolusi spasial dibawah $1 \mathrm{~cm}$. Penelitian tentang klasifikasi spesies mangrove dengan citra drone masih terbatas, juga belum ada referensi apakah bila pada citra drone resolusi dan ukuran datanya dikurangi, ketepatan klasifikasi datanya akan berkurang, dan sejauh mana pengurangan itu terjadi. Disini kami berhipotesis bahwa akan ada hubungan linear antara resolusi dan ketepatan klasifikasi spesies bakau, dimana pengurangan resulusi akan mengurangi akurasi klasifikasi. Akan tetapi, hasil percobaan berulang (9 iterasi) dengan 8 resolusi spasial yang berbeda, yaitu $2.5 \mathrm{~cm}, 5 \mathrm{~cm}, 10 \mathrm{~cm}, 20 \mathrm{~cm}, 40 \mathrm{~cm}, 60 \mathrm{~cm}, 80 \mathrm{~cm}$ dan $100 \mathrm{~cm}$ menunjukkan tidak signifikannya penurunan akurasi klasifikasi saat resolusi spatial, mematahkan hipotesis awal tersebut. Overall Accuracy (OA) pada resolusi $2.5 \mathrm{~cm}$ adalah $84.97 \pm 2.37 \%$, sedangkan pada $60 \mathrm{~cm}$ adalah $88.61 \pm 3.6 \%$. Alih -alih menunjukkan pengurangan, malah menunjukkan peningkatan walaupun tidak signifikan. Pada resolusi $100 \mathrm{~cm}$, akurasi menurun drastis $(\mathrm{OA}=\mathbf{2 0 . 7 2} \pm \mathbf{1 . 2 4 \%})$. Berdasarkan hasil tersebut, kami merekomendasikan dalam mengidentifikasi spesies mangrove dengan citra drone, resolusi yang optimum adalah $60 \mathrm{~cm}$, resolusi ini dapat memberikan pengurangan waktu klasifikasi yang signifikan (dari 15 menit ke 2.5 detik) serta yang terpenting adalah memberikan ketepatan tertinggi untuk spesies dengan heterogenitas penampakan yang tinggi seperti palem $N$. fruticans, tanpa mengurangi ketepatan akurasi pada spesies pohon seperti $R$. apiculata dan A. alba.
\end{abstract}


Ruwaimana dkk.,

Kata kunci: Drone, UAV, bakau, resolusi spasial, Maximum Likelihood

Diterima: 6 September 2017, disetujui: 30 September 2017

\section{Pendahuluan}

Penginderaan jauh atau remote sensing adalah salah satu metode penelitian untuk pemetaan dan pengamatan lingkungan dan bentang alam. Sebelumnya, studi penginderaan jauh (remote sensing) hanya menggunakan dua sumber, yaitu citra satelit dan citra dari pesawat berawak ( Green, Mumby, Edwards, \& Clark, 2000). Citra satelit memiliki keunggulan yaitu luas area tutupan yang besar, serta beberapa citra satelit resolusi rendah sudah tersedia secara gratis (Sulong, Mohd-Lokman, Mohd-Tarmizi, \& Ismail, 2002). Tetapi untuk penelitian dan monitoring di area tropis seperti Indonesia, tingginya tutupan awan seringkali membatasi kualitas citra yang dapat diperoleh melalui satelit (Gastellu-Etchegorry, 1988). Alternatif lainnya adalah dengan menggunakan citra dari pesawat berawak. Metode ini tidak lagi dibatasi oleh tutupan awan karena pesawat pemetaan seringkali terbang di bawah awan (Sulong dkk., 2002; Verheyden, Dahdouh-Guebas, \& Koedam, 2002). Sayangnya, metode ini memiliki biaya operasional yang cukup tinggi (ITRES, 2016). Munculnya drone atau Unmanned Aerial Vehicle (UAV) yang telah tersedia secara komersial dan harganya semakin ekonomis, memunculkan potensi besar sebagai alat untuk analisis lingkungan dan ekologi, contohnya dalam monitoring lahan pertanian, kebakaran hutan, persebaran lumut di kutub dan pemetaan hutan bakau (Crutsinger, Short, \& Sollenberger, 2016; Floreano \& Robert, 2015).

Drone juga dapat terbang jauh lebih rendah dibandingkan pesawat pemetaan, sehingga citra yang ditangkap akan lebih detail atau memiliki resolusi spasial yang tinggi; citra drone dapat mencapai resolusi spasial hingga dibawah $1 \mathrm{~cm}$, jauh lebih detail dibandingkan dengan satelit $(30 \mathrm{~cm})$ dan pesawat $(10 \mathrm{~cm})$ (CNES, 2012; B. Satyanarayana dkk., 2011; Sulong dkk., 2002). Meskipun resolusi yang tinggi ini dapat memberikan informasi yang lebih detail untuk analisis, resolusi tinggi juga akan meningkatkan ukuran data dari citra itu sendiri, sebagai perbandingan, citra drone dengan resolusi $5 \mathrm{~cm}$ memiliki ukuran data 20 kali lipat dibandingkan dengan citra satelit dengan resolusi $50 \mathrm{~cm}$ (Ruwaimana, 2016). Sejauh ini, penelitian menggunakan drone masih dalam tahap uji coba untuk area yang relatif kecil, dan kurang dari 100 ha (Lucieer, Robinson, \& Turner, 2010; Ventura, Bruno, Jona Lasinio, Belluscio, \& Ardizzone, 2016). Untuk pemetaan area yang luas, maka akan dihasilkan ukuran data yang besar. Di satu sisi, hal ini memungkinkan pemetaan yang tepat dan mendetail, tetapi di sisi lain hal ini juga akan meningkatkan jangka waktu yang diperlukan untuk melakukan analisis, sehingga menurunkan efisiensi dan kecepatan pemetaan.

Salah satu analisis yang umum dilakukan dalam remote sensing dan pemetaan vegetasi adalah klasifikasi tutupan lahan secara otomatis, yaitu membedakan berbagai jenis objek. Dalam hal ini objek tersebut adalah mangrove, yang berada pada gambar sesuai dengan warna atau panjang gelombang yang dipantulkan oleh objek tersebut (Foody, 2002; Green dkk., 2000; Khatami, Mountrakis, \& Stehman, 2016). Hutan bakau, yang tumbuh di area estuari atau muara sungai di daerah tropis umumnya memiliki jumlah spesies yang tidak terlalu tinggi, dengan kurang dari 10 spesies pohon yang mendominasi sehingga cocok untuk digunakan sebagai percobaan dalam klasifikasi otomatis berbagai jenis spesies pohon yang berbeda (Mukherjee, Sutherland, Khan, Berger, \& Schmitz, 2014).

Analisis klasifikasi spesies dengan citra drone masih terbatas dan belum ada referensi apakah bila citra drone resolusi dan ukuran datanya dikurangi, ketepatan klasifikasi datanya akan berkurang, dan sejauh mana pengurangan itu terjadi. Dalam hal ini dapat diduga bahwa akan ada hubungan linear antara resolusi dan ketepatan klasifikasi spesies bakau. Oleh karena itu, tujuan dalam penelitian ini adalah menemukan resolusi citra drone yang paling optimum, dengan jangka waktu proses klasifikasi yang paling cepat dan dengan ketepatan klasifikasi data tertinggi. 


\section{Metode Penelitian}

\section{Pengambilan Foto Drone}

Foto drone diambil pada bulan Juni 2015 di Setiu Wetland, Malaysia, dan terdiri dari 244 foto yang diambil dengan menggunakan drone DJI Phantom 2 yang dikontrol secara otomatis dengan DJI 2.4G Datalink. Drone ini terbang mengikuti jalur yang telah direncanakan menggunakan program DJI Ground Station v.04. Drone terbang dengan ketinggian $100 \mathrm{~m}$ dari permukaan laut. Kamera yang digunakan adalah SJ4000wifi (12megapixel, wide angle, panjang fokal $24 \mathrm{~mm}$ dengan sensor CMOS $22 \mathrm{~mm} \times$ $36 \mathrm{~mm})$. Kamera menangkap gambar setiap dua detik, sehingga didapatkan hasil $75 \%$ overlap antara setiap foto.

\section{Pengolahan Citra Drone}

Foto diberikan koordinat dengan mensinkronisasikan catatan GPS dari alat Flytrex yang menempel pada drone dan waktu foto pada kamera (Flytrex, 2015) Sinkronisasi ini dilakukan menggunakan program Geosetter@ (Schmidt, 2011). Foto yang telah berkoordinat akan digabungkan menjadi satu citra menggunakan program Agisoft Photoscan(C) (Perry, 2013) dengan 7 ground control point (GCP) dari Google EarthTM, dan dengan interpretasi visual berdasarkan pengalaman saat mengambil gambar di lokasi tersebut. Program ini akan menyusun dan membuat foto saling tindih secara otomatis berdasarkan koordinatnya. Citra kemudian dieksport ke dalam berbagai variasi resolusi spasial, yaitu $2,5 \mathrm{~cm}, 5 \mathrm{~cm}, 10 \mathrm{~cm}$, $20 \mathrm{~cm}, 40 \mathrm{~cm}, 60 \mathrm{~cm}, 80 \mathrm{~cm}$ dan $100 \mathrm{~cm}$. Refensi koordinat disesuaikan pada EPSG: 32648 WGS $84 / \mathrm{UTM}$ zone $48 \mathrm{~N}$.

\section{Klasifikasi Spesies}

Citra drone diklasifikasi dengan program Quantum Geographic Information System
(QGIS) version 2.18.15-Las Palmas (QGISDevelopment-Team, 2018), dengan alokasi RAM khusus untuk software ini sebesar 4GB. Untuk klasifikasi secara otomatis, diperlukan training sites berupa area yang sudah dipastikan di lapangan bahwa terdiri dari satu spesies tertentu saja, yang akan digunakan sebagai referensi untuk sofware dalam melakukan identikasi spesies dan untuk melakukan validasi terhadap akurasi identifikasi tersebut. Training sites dibentuk menggunakan Semi-Automatic Classification Plugin (SCP) dalam QGIS (Congedo, 2014). Berdasarkan data lapangan, visualisasi langsung dan percobaan dengan menggunakan unsupervised classification, citra drone akan diidentifikasi menjadi 5 kelas, yaitu air, tanah, Rhizophora apiculata, Avicennia alba dan Nypa fruticans.

Ada 3 algoritma klasifikasi yang tersedia pada SCP QGIS, yaitu Maximum Likelihood, Spectral Angle Mapping dan Minimum Distance (Congedo, 2014). Pada percobaan awal yang dilakukan, didapatkan hasil bahwa Maximum Likelihood memiliki hasil yang tertinggi, dan ini didukung juga oleh beberapa penelitian sebelumnya dalam klasifikasi mangrove. (Khatami dkk., 2016; Behara Satyanarayana, Mohamad, Idris, Husain, \& Dahdouh-Guebas, 2011; Wang, Sousa, \& Gong, 2004). Oleh karena itu, algoritma Maximum Likelihood dipilih untuk digunakan dalam penelitian ini.

Citra yang sudah diklasifikasi akan dibandingkan dengan training sites dan memberikan hasil berupa error matrix. Dari error matrix, akurasi dapat ditampilkan dengan menghitung 3 indeks, yaitu Overall Accuracy (OA) untuk keseluruhan gambar, serta User Accuracy (UA) dan Producer Accuracy (PA) untuk setiap kelas objek. Proses klasifikasi dan validasi ini dilakukan berulang sebanyak 9 kali untuk memastikan keabsahan hasil 
Ruwaimana dkk.,

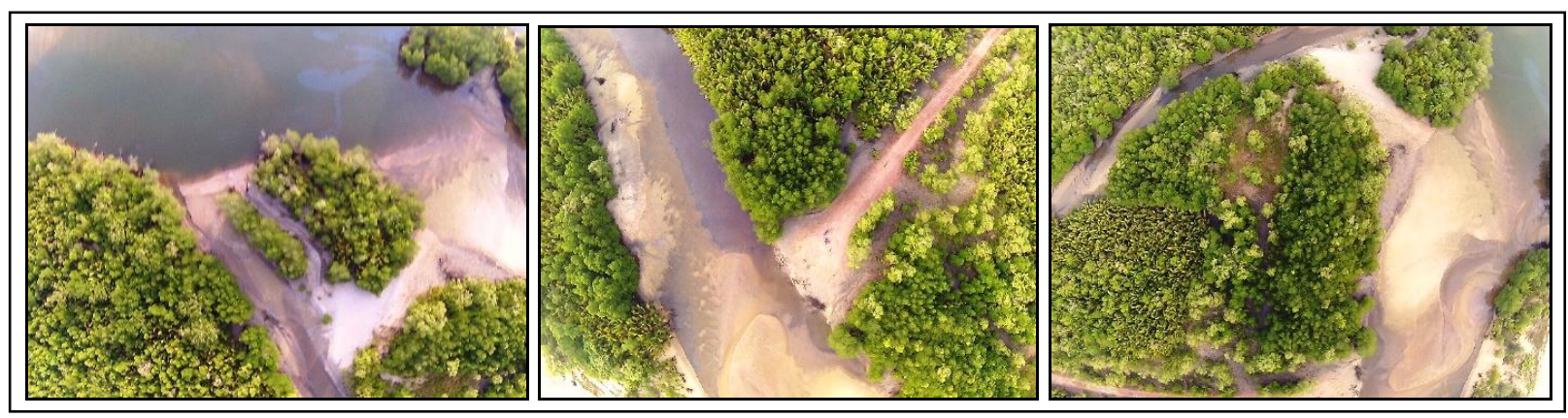

Gambar 1. Contoh foto mangrove yang diambil dengan menggunakan Drone DJI Phantom II dengan kamera SJ CAM 4000 dari ketinggian 100m. (Dok. pribadi).

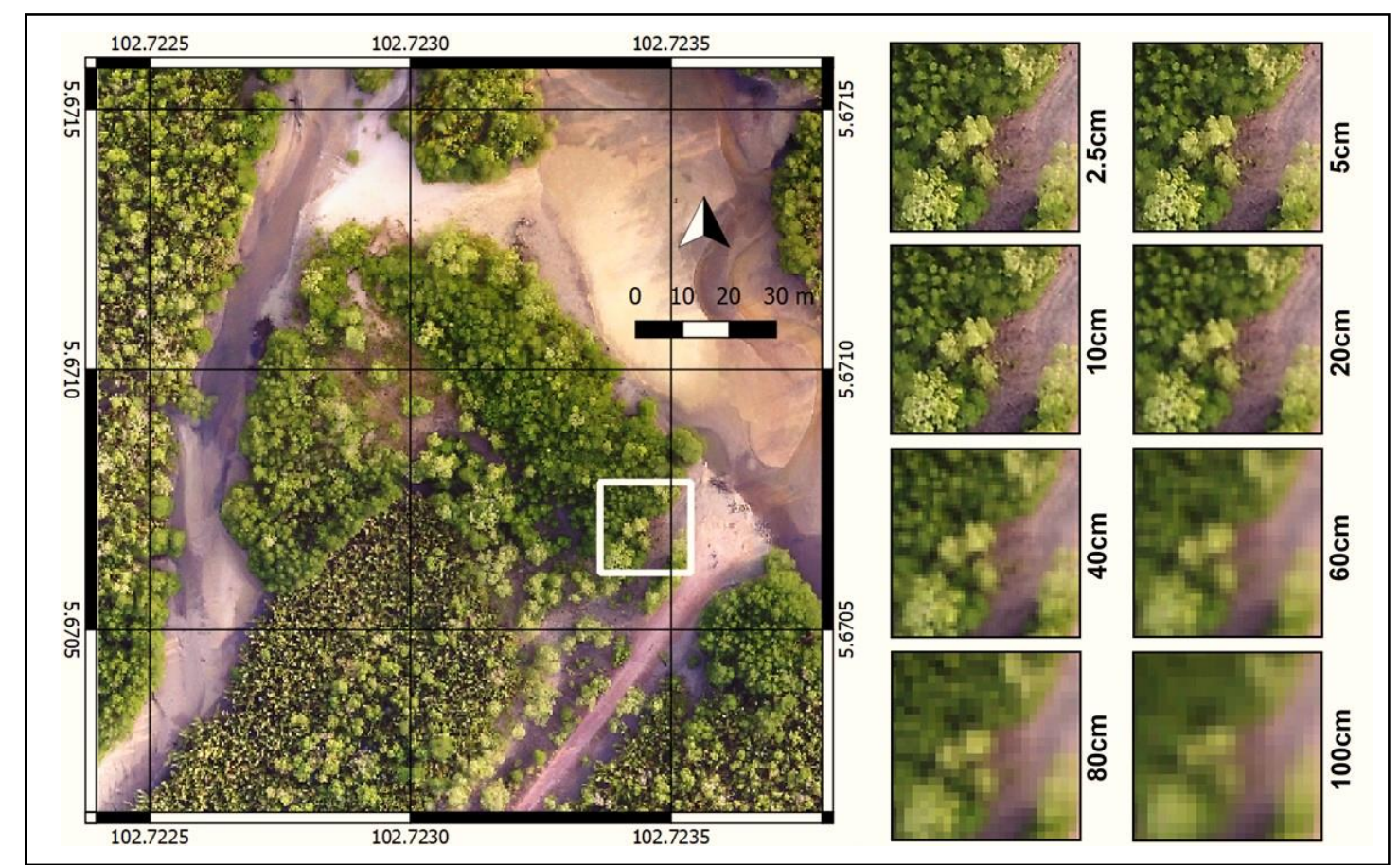

Gambar 2. Hasil penggabungan foto drone, disertai subset dalam berbagai resolusi spasial, yaitu $2,5 \mathrm{~cm}, 5 \mathrm{~cm}, 10 \mathrm{~cm}, 20 \mathrm{~cm}, 40 \mathrm{~cm}, 60 \mathrm{~cm}, 80 \mathrm{~cm}$ dan $100 \mathrm{~cm}$.

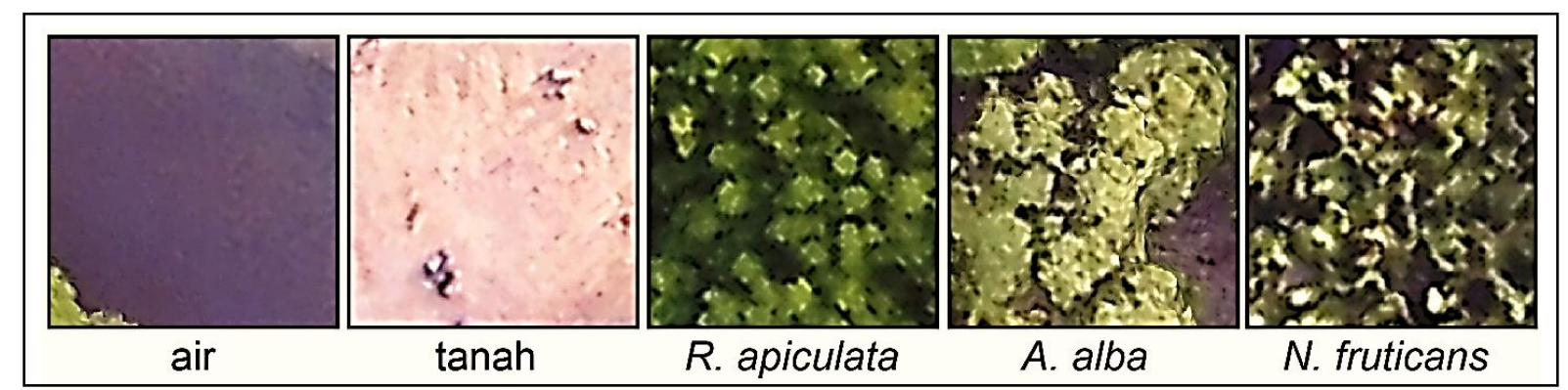

Gambar 3. Lima kelas tutupan lahan (land cover) dari citra drone, yaitu air, tanah, Rhizophora apiculata, Avicennia alba dan Nypa fruticans. 


\section{Analisis Statistik}

Oleh karena data tidak terdistribusi normal, maka untuk mengetahui ada tidaknya perbedaan antar grup, analisis non-parametrik dilakukan pada parameter waktu proses klasifikasi, Overall Accuracy, Producer Accuracy dan User Accuracy dengan program Past 3 (Hammer, Harper, \& Ryan, 2011). Analisis dilakukan menggunakan KruskallWallis dan Mann-Whitney pairwise, diikuti dengan Bonferroni Correction untuk nilai $\mathrm{p}$. Selain itu, median dan standar deviasi untuk setiap parameter dan resolusi juga akan dihitung.

\section{Hasil dan Pembahasan}

Klasifikasi telah dilakukan pada citra drone yang diambil di Setiu Wetland, pixel dalam citra drone tersebut dikategorikan menggunakan algoritma komputer menjadi lima jenis tutupan lahan yang berbeda, yaitu tiga spesies mangrove ( $R$. apiculata, A. alba dan $N$. fruticans) serta dua tutupan lahan yang bersifat abiotik, yaitu air dan tanah (Gambar 4). Klasifikasi ini dilakukan berdasarkan warna atau panjang gelombang yang dipantulkan oleh pixel dalam citra drone tersebut (Foody, 2002; Green et al., 2000; Khatami dkk., 2016).

Citra drone dengan resolusi yang berbedabeda menghasilkan waktu proses klasifikasi yang berbeda, dan ketepatan klasifikasi yang juga berbeda. Kombinasi waktu dan ketepatan klasifikasi inilah menjadi acuan resolusi manakah yang paling optimum dalam klasifikasi spesies mangrove pada citra drone. Waktu klasifikasi dan ketepatan klasifikasinya dapat dilihat pada Tabel 1, terdapat ukuran data terkait dengan waktu klasifikasi, serta berbagai parameter ketepatan klasfikasi, yaitu OA (Overall Accuracy) secara umum, serta PA (Producer Accuracy) dan UA (User Accuracy) secara spesifik untuk setiap jenis spesies.

Parameter pertama dalam menentukan resolusi citra drone yang optimum adalah lama waktu proses klasifikasi. Resolusi citra drone yang tinggi akan menghasilkan waktu klasifikasi yang lama, dan sebaliknya, resolusi yang rendah hanya memerlukan waktu yang singkat untuk klasifikasi. Hal ini terkait pada ukuran data image dimana resolusi $2.5 \mathrm{~cm}$ memiliki ukuran
$150.585 \mathrm{~kb}$, sementara resolusi $100 \mathrm{~cm}$ ukuran datanya 1500 kali lebih kecil, yaitu hanya $94 \mathrm{~kb}$. Ukuran data yang kecil akan lebih mudah diproses oleh algoritma komputer, dan ini menghasilkan pengurangan pada lama waktu klasifikasi spesies. Lama waktu klasifikasi dari resolusi $2.5 \mathrm{~cm}$, yaitu 15,4 menit (926 detik) berkurang secara signifikan hingga ke resolusi $40 \mathrm{~cm}$, yaitu 3.9 detik atau 300 kali lebih cepat. Akan tetapi, pada resolusi $60-100 \mathrm{~cm}$, tidak ada perbedaan yang signifikan, proses klasifikasinya hanya membutuhkan 2 detik (Tabel 1, Gambar 5).

Hasil menunjukkan bahwa dengan mengurangi resolusi, waktu proses klasifikasi akan lebih cepat. Dalam penelitian ini, luas wilayah yang diuji adalah $180 \times 180 \mathrm{~m}^{2}$ atau sekitar 3.24ha. Sementara di lapangan, pemetaan umumnya dilakukan pada wilayah dengan luas lebih dari 100ha, sehingga untuk menganalisis data dengan resolusi $2.5 \mathrm{~cm}$, akan diperlukan waktu lebih dari 7jam, sementara bila data dikurangi resolusinya menjadi $40 \mathrm{~cm}$, hanya diperlukan waktu yang jauh lebih cepat, yaitu sekitar1.5menit. Pengurangan waktu klasifikasi ini diperlukan agar pemetaan lebih efisien, dan opsinya adalah meningkatkan kekuatan komputer atau alokasi RAM untuk software, atau mengurangi resolusi dari gambar tersebut. Berdasarkan hasil lama waktu klasifikasi, resolusi yang optimum yaitu tidak ada lagi pengurangan waktu yang signifikan adalah antara $60 \mathrm{~cm}$ hingga $100 \mathrm{~cm}$.

Parameter kedua yang lebih penting dalam menentukan ketepatan dalam klasifikasi merupakan ketepatan klasifikasi. Hipotesis dalam penelitian ini menyatakan bahwa saat resolusi data diturunkan, maka akurasi pemetaan juga akan menurun. Hal ini telah diuji dengan membandingkan Overall accuracy (OA) dari berbagai resolusi, dan didapatkan bahwa penurunan resolusi spasial hingga $80 \mathrm{~cm}$ tidak menyebabkan penurunan signifikan, bahkan terjadi sedikit peningkatan pada resolusi $60 \mathrm{~cm}$ meskipun tidak signifikan (Tabel 1, Gambar 5). Hasil ini bertentangan dengan hipotesis awal. Berdasarkan hasil ini, dalam pemetaan mangrove menggunakan drone, resolusi spasial dapat dikurangi hingga $80 \mathrm{~cm}$ dengan pertimbangan penghematan waktu analisis dan bahwa tidak adanya perbedaan signifikan antara akurasinya. 
Tidak signifikannya penurunan ini terkait dengan ukuran objek yang dianalisis, yaitu kanopi pohon mangrove (terutama $R$. apiculata dan A. alba) yang berdiameter sekitar 3-6m. Ketika resolusi turun dibawah $80 \mathrm{~cm}$, maka batas kanopi ini akan tampak menyatu (Gambar 2), sehingga menyebabkan kesalahan dalam klasifikasi. Ini terlihat pada Producer dan User Accuracy (PA dan UA), dimana tidak ada perbedaan akurasi yang signifikan saat resolusi diturunkan ke $80 \mathrm{~cm}$, namun akurasi menurun drastis pada resolusi $100 \mathrm{~cm}$.

Hal yang bertentangan terjadi pada spesies $N$. fruticans, spesies palem ini memiliki penampakan yang heterogen akibat dari ukuran daunnya yang relatif kecil dibandingkan kanopi pohon mangrove lainnya (Gambar 3). Heterogenitas ini menghilang ketika resolusi diturunkan dan $N$. frutican terlihat menyatu, sehingga PA menjadi lebih tepat pada resolusi 20, 40 dan $80 \mathrm{~cm}$ dan paling tepat pada resolusi $60 \mathrm{~cm}$ (Tabel 1, Gambar 6), ini menyebabkan peningkatan ketepatan pada resolusi yang rendah. Berdasarkan hasil tersebut, kami merekomendasikan untuk mengklasifikasi spesies pohon dengan heterogenitas penampakan rendah, penurunan resolusi hingga $80 \mathrm{~cm}$ tidak memberikan pengaruh apa-apa, namun untuk spesies palem $N$. fruticans, resolusi yang optimum adalah $60 \mathrm{~cm}$.

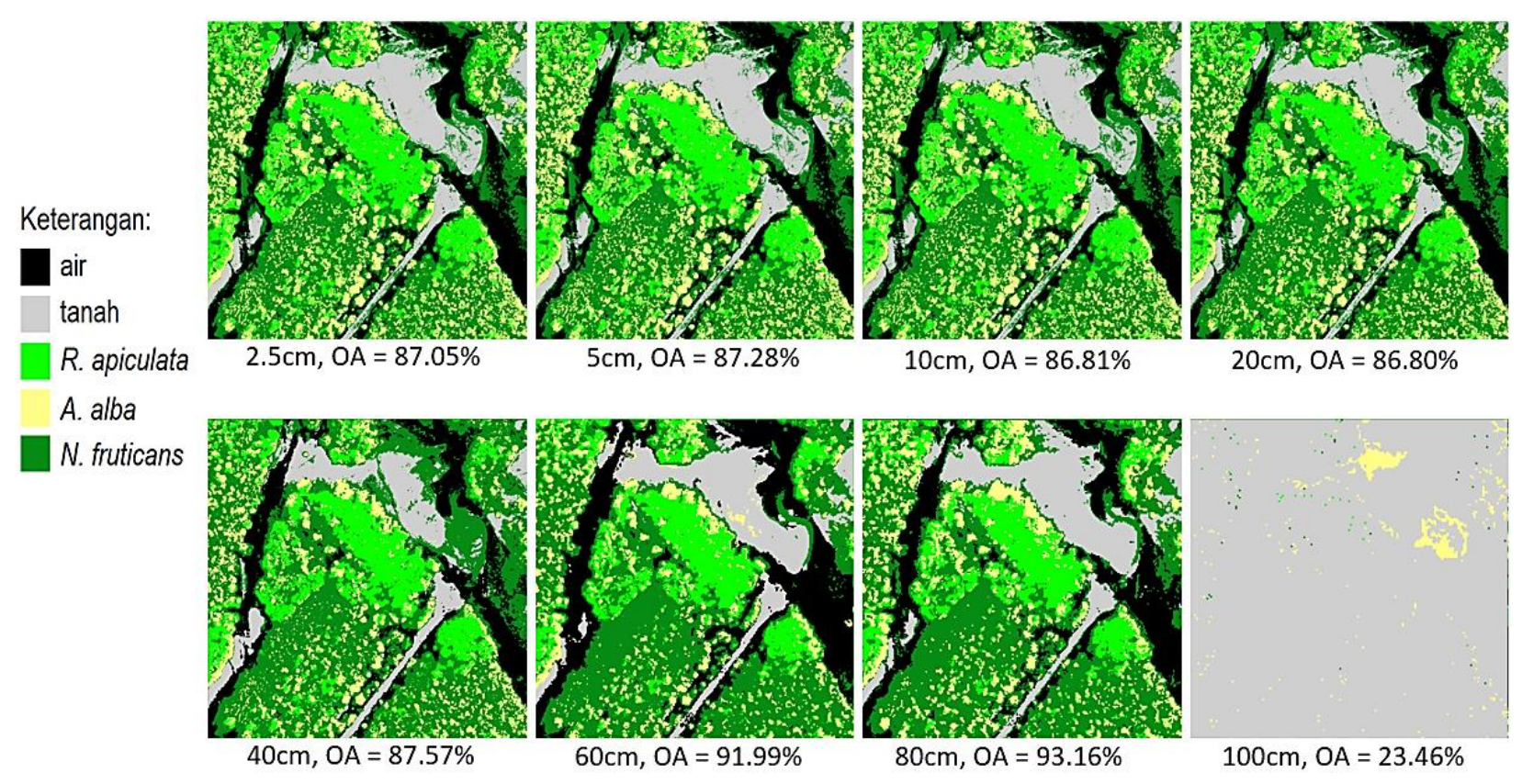

Gambar 4. Peta vegetasi mangrove hasil klasifikasi dengan resolusi spatial yang berbeda $(2,5 \mathrm{~cm}, 5 \mathrm{~cm}, 10 \mathrm{~cm}, 20 \mathrm{~cm}$, $40 \mathrm{~cm}, 60 \mathrm{~cm}, 80 \mathrm{~cm}$ dan $100 \mathrm{~cm}$ ), dengan Overall Accuracy $(\mathrm{OA})$ tertinggi dari 9 pengulangan klasifikasi per resolusi. Resolusi $100 \mathrm{~cm}$ memiliki perbedaan akurasi yang sangat signifikan bila dibandingkan dengan resolusi lainnya. 

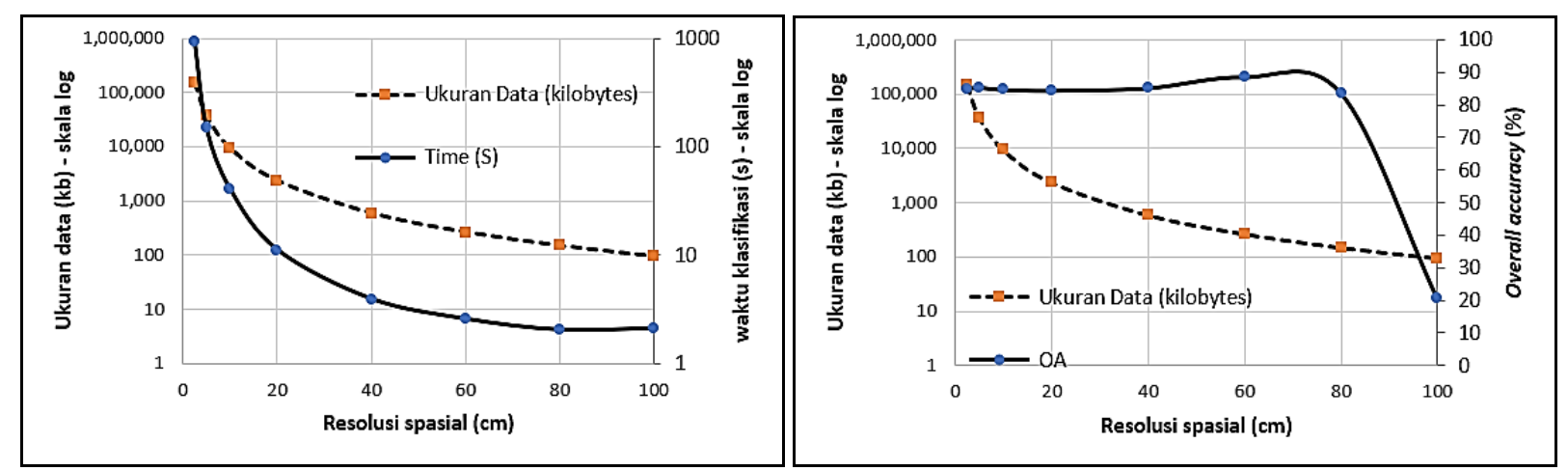

Gambar 5. Kiri: Perbandingan median dari ukuran data (dalam satuan kilobytes dan skala logaritmik) dengan waktu klasifikasi (dalam satuan detik dan skala logaritik) untuk berbagai resolusi spasial. Kanan: Perbandingan median dari ukuran data (dalam satuan kilobytes dan skala logaritmik) dengan Overall Accuracy (dalam satuan \%) untuk berbagai resolusi spasial.

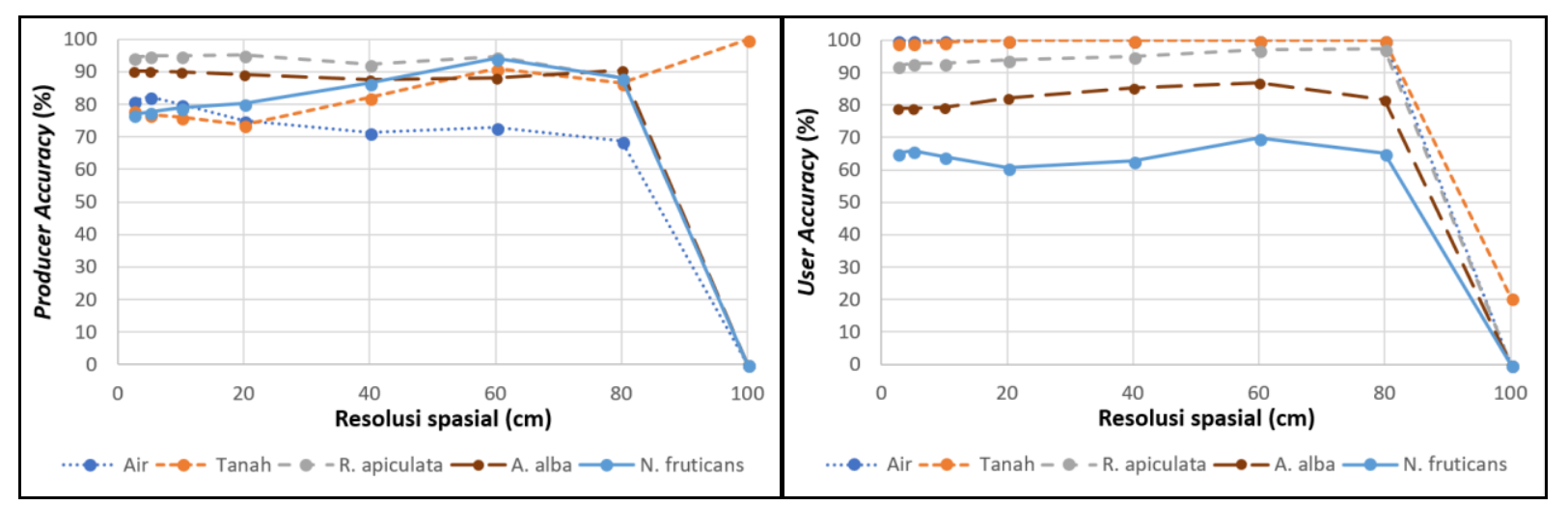

Gambar 6. Kiri: Hasil Producer Accuracy (PA), Kanan: Hasil User Accuracy (UA) dari citra drone dengan resolusi yang berbeda $(2,5 \mathrm{~cm}, 5 \mathrm{~cm}, 10 \mathrm{~cm}, 20 \mathrm{~cm}, 40 \mathrm{~cm}, 60 \mathrm{~cm}, 80 \mathrm{~cm}$ dan $100 \mathrm{~cm})$ untuk setiap jenis kelas tutupan lahan, yaitu air, tanah, Rhizophora apiculata, Avicennia alba dan Nypa fruticans.

Tabel 1.Ukuran data, lama waktu klasifikasi dan hasil Overall Accuracy (OA), User Accuracy (UA) dan Producer Accuracy (PA) untuk setiap resolusi spasial yang diuji $(2,5 \mathrm{~cm}, 5 \mathrm{~cm}, 10 \mathrm{~cm}, 20 \mathrm{~cm}, 40 \mathrm{~cm}, 60 \mathrm{~cm}, 80 \mathrm{~cm}$ dan $100 \mathrm{~cm})$. Median dan standar deviasi didapatkan dari 9 kali pengulangan, dan huruf di belakang angka adalah grup dengan perbedaan signifikan

\begin{tabular}{|c|c|c|c|c|c|c|c|c|c|c|c|c|c|c|}
\hline Resolu & $2.5 \mathrm{~cm}$ & & $5 \mathrm{cr}$ & & $10 \mathrm{~cm}$ & & $20 \mathrm{~cm}$ & & $40 \mathrm{~cm}$ & & $60 \mathrm{~cm}$ & $80 \mathrm{~cm}$ & $100 \mathrm{~cm}$ & \\
\hline Jkuran Data (kb) & 150585.02 & & 37666. & & 9418.77 & & 2355.30 & & 591.28 & & 264.61 & 148.62 & 94.70 & \\
\hline Vaktu (s) & $926.71 \pm 57.2$ & & $149.82 \pm$ & 149.8 & $3 \pm 0.7$ & c & $11.16 \pm 0.3$ & d & $3.92 \pm 0.4$ & e & $2.56 \pm 0.5$ & $2.03 \pm 0.4$ & $.09 \pm 0.5$ & \\
\hline DA & $84.97 \pm 2.4$ & & $85.37 \pm$ & $2.7^{\mathrm{a}}$ & $84.73 \pm 2.6$ & a & $84.42 \pm 2.7$ & a & $85.22 \pm 3.8$ & a & $88.61 \pm 3.7^{a}$ & $83.76 \pm 5.1 \quad a$ & $20.72 \pm 1.2$ & b \\
\hline PA air & $81.01 \pm 11.9^{\circ}$ & & $82.24 \pm$ & $12.6^{\mathrm{a}}$ & $79.98 \pm 13.4$ & & $75.06 \pm 14.5$ & & $71.27 \pm 16.5^{\circ}$ & & $73.02 \pm 18.5^{a}$ & $68.83 \pm 20.7^{\text {a }}$ & $0.00 \pm 0.0$ & b \\
\hline A tanah & $78.12 \pm 6.9$ & a & $76.86 \pm$ & $6.9^{a}$ & $75.94 \pm 7.0$ & a & $73.67 \pm 8.3$ & a & $82.13 \pm 7.6$ & a & $91.11 \pm 6.5^{a}$ & $86.42 \pm 11.8^{a}$ & $100.00 \pm 0.0$ & b \\
\hline A R. apicul & $94.46 \pm 4.1$ & a & $94.87 \pm$ & $4.7^{\mathrm{a}}$ & $94.98 \pm 4.4$ & a & $95.06 \pm 4.1$ & a & $92.28 \pm 4.9$ & a & $94.74 \pm 7.3 \quad$ a & $88.24 \pm 9.9$ a & $0.00 \pm 0.0$ & 0 \\
\hline A A. alba & $90.24 \pm 3.9$ & a & $90.21 \pm$ & $3.8^{\mathrm{a}}$ & $90.00 \pm 3.8$ & a & $89.14 \pm 4.0$ & a & $87.71 \pm 5.5$ & a & $88.24 \pm 5.7^{a}$ & $90.36 \pm 6.6$ a & $0.00 \pm 1.4$ & o \\
\hline A N. frutica & $76.80 \pm 3.5$ & a & $77.69 \pm$ & $3.4^{\mathrm{a}}$ & $79.02 \pm 3.2$ & a & $80.23 \pm 3.3$ & ab & $86.49 \pm 3.1$ & b & $94.03 \pm 3.1 \quad c$ & $88.16 \pm 2.3 \quad b$ & $0.00 \pm 0.0$ & d \\
\hline A air & $99.99 \pm 0.0$ & a & $100.00 \pm$ & $0.0^{\mathrm{a}}$ & $100.00 \pm 0.0$ & a & $100.00 \pm 0.0$ & a & $100.00 \pm 1.9$ & a & $100.00 \pm 0.3$ & 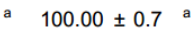 & $0.00 \pm 0.0$ & b \\
\hline JA tanah & $99.14 \pm 0.4$ & a & $99.18 \pm$ & $0.4^{\mathrm{a}}$ & $99.53 \pm 0.3$ & a & $99.90 \pm 0.1$ & ab & $100.00 \pm 0.1$ & b & $100.00 \pm 0.0$ & b $\quad 100.00 \pm 0.0$ & $20.72 \pm 1.1$ & c \\
\hline JA R. apiculata & $92.17 \pm 3.8$ & a & $92.80 \pm$ & $3.8^{\mathrm{a}}$ & $92.77 \pm 3.7$ & a & $93.84 \pm 3.8$ & a & $95.07 \pm 3.8$ & 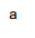 & $97.10 \pm 3.0^{a}$ & $97.37 \pm 4.2 \quad$ a & $0.00 \pm 0.0$ & b \\
\hline JA A. alba & $79.03 \pm 3.1$ & a & $78.94 \pm$ & $3.3^{a}$ & $79.39 \pm 3.3$ & a & $82.07 \pm 3.2$ & a & $85.28 \pm 4.3$ & a & $86.86 \pm 7.8 \quad a$ & $81.72 \pm 6.6$ & $0.00 \pm 33.3$ & \\
\hline JA N. fruticans & $65.09 \pm 6.0$ & a & $66.00 \pm$ & $6.5^{\mathrm{a}}$ & $64.20 \pm 6.5$ & a & $60.69 \pm 6.0$ &  & $62.78 \pm 7.9$ & . & $69.78 \pm 9.1 \quad$ a & $65.09 \pm 11.3$ & $0.00 \pm 0.0$ & \\
\hline
\end{tabular}




\section{Simpulan}

Resolusi citra drone yang optimum telah behasil ditentukan dalam penelitian ini Berdasarkan lama waktu klasifikasi, resolusi $60 \mathrm{~cm}-100 \mathrm{~cm}$ memiliki lama waktu proses yang paling singkat. Berdasarkan ketepatan klasifikasi, penurunan hingga $80 \mathrm{~cm}$ tidak menunjukkan pengurangan resolusi yang signifikan. Tidak signifikannya penurunan akurasi klasifikasi saat resolusi spatial diturunkan mematahkan hipotesis awal bahwa adanya hubungan linear antara resolusi spasial dan akurasi.

Berdasarkan kombinasi hasil ketepatan dan kecepatan waktu kalsifikasi, kami merekomendasikan dalam mengidentifikasi spesies mangrove dengan citra drone, resolusi yang optimum adalah $60 \mathrm{~cm}$, dimana resolusi ini memberikan ketepatan tertinggi untuk spesies dengan heterogenitas penampakan yang tinggi seperti $N$. fruticans, tetapi tidak mengurangi ketepatan akurasi pada spesies pohon seperti $R$. apiculata dan A. alba.

\section{Ucapan Terima Kasih}

Terima kasih pada Lembaga Penelitian dan Pengabdian Masyarakat Universitas Atma Jaya Yogyakarta yang telah mendanai pembelian software untuk penelitian ini, dan pada Program TROPIMUNDO Erasmus Mundus yang mendanai pembelian drone dan pengambilan data lapangan, serta Universiti Malaysia Terengganu yang juga mendukung dalam pengambilan data lapangan di Malaysia.

\section{Daftar Pustaka}

CNES. 2012. Pleiades User Guide. ASTRIUM.

Congedo, L. 2014. Semi-Automatic Classification Plugin Documentation Vers 3.0.7.

Crutsinger, G. M., Short, J., dan Sollenberger, R. 2016. The future of UAVs in ecology: an insider perspective from the Silicon Valley drone industry. Journal of Unmanned Vehicle Systems, 4 (1): 1-8.

Floreano, D. dan Robert, J.W. 2015. Science, technology and the future of small autonomous drones. Nature, 521 (7553): 460-466.
Flytrex. 2015. Flytrex Core V2.

Foody, G.M. 2002. Status of land cover classification accuracy assessment. Remote Sensing of Environment, 80: 185-201.

Gastellu-Etchegorry, J.P. 1988. Cloud cover distribution in Indonesia. International Journal of Remote Sensing, 9 (7): 1267-1276.

Green, E.P., Mumby, P.J., Edwards, A.J. dan Clark, C.D. 2000. Remote sensing book for tropical coastal management (Coastal Ma). Paris: UNESCO.

Hammer, Ø., Harper, D.A.T. dan Ryan, P.D. 2011. PAST: Paleontological statistics software package for education and data analysis. Palaeontologia Electronica, 4 (1): 9pp.

ITRES. 2016. CASI 1500h Specification.

Khatami, R., Mountrakis, G. dan Stehman, S.V. 2016. A meta-analysis of remote sensing research on supervised pixel-based land-cover image classification processes : General guidelines for practitioners and future research. Remote Sensing of Environment, 177: 89-100.

Lucieer, A., Robinson, S.A. dan Turner, D. 2010. Using an unmanned aerial vehicle (UAV) for ultra- high resolution mapping of Antarctic moss beds. In Australasian Remote Sensing \& Photogrammetry Conference (pp. 1-12). Alice Springs, NT, Australia.

Mukherjee, N., Sutherland, W.J., Khan, N.I., Berger, U. dan Schmitz, N. 2014. Using expert knowledge and modeling to define mangrove composition, functioning, and threats and estimate time frame for recovery. Ecology and Evolution, 4 (11): 2247-2262.

Perry, T.S. 2013. Agisoft's PhotoScan. Animation, 27 (2). (computer software documentation)

QGIS-Development-Team. 2018. QGIS Geographic Information System. Open Source Geospatial Foundation Project.

Ruwaimana, M. 2016. Like a drone come true: Comparison of Satellite and Drone Imagery for Mangrove Mapping in Setiu Wetland, Malaysia. Brussels.

Satyanarayana, B., Koedam, N., Smet, K.D., Nitto, D.D., Bauwens, M., Jayatissa, L.P., Dahdouh-Guebas, F. 2011. Long-term mangrove forest development in Sri Lanka: early predictions evaluated against outcomes using VHR remote sensing and VHR ground-truth data. Marine Ecology Progress Series, 443: 51-63.

Satyanarayana, B., Mohamad, K.A., Idris, I.F., Husain, M. L. dan Dahdouh-Guebas, F. 2011. Assessment of mangrove vegetation based on remote sensing and ground-truth measurements at Tumpat, Kelantan Delta, East Coast of Peninsular Malaysia. International Journal of Remote Sensing, 32 (6): 1635-1650. https://doi.org/10.1080/01431160903586781 


\section{Resolusi Spasial Optimum pada Citra Drone}

Schmidt, F. 2011. Geosetter Version 3.4.16. (computer software documentation)

Sulong, I., Mohd-Lokman, H., Mohd-Tarmizi, K. dan Ismail, A. 2002. Mangrove mapping using Landsat imagery and aerial photographs: Kemaman District, Terengganu, Malaysia. Environment, Development and Sustainability, 4(2), 135-152. https://doi.org/10.1023/A: 1020844620215

Ventura, D., Bruno, M., Jona Lasinio, G., Belluscio, A. dan Ardizzone, G. 2016. A low-cost drone based application for identifying and mapping of coastal fish nursery grounds. Estuarine, Coastal and Shelf Science, 171, 85-98. https://doi.org/10.1016/j.ecss.2016.01.030
Verheyden, A., Dahdouh-Guebas, F. dan Koedam, N. 2002. High-Resolution Vegetation Data for Mangrove Research as Obtained from Aerial Photography. Environment, Development and Sustainability, 4: 113-133.

Wang, L., Sousa, W. P. dan Gong, P. 2004. Integration of object-based and pixel-based classification for mapping mangroves with IKONOS imagery. International Journal of Remote Sensing, 25 (24), 5655-5668. https://doi.org/10.1080/ 014311602331291215. 